مكانيابى مناطق مستعد يخش سيلاب با استفاده از منطق فازى و فر آيند تحليل شبكهاى (ANP) (مطالعه موردى: دشت مشهد)

احسان زاهدى، فرشيد جهانبخشى" و على طالبى'

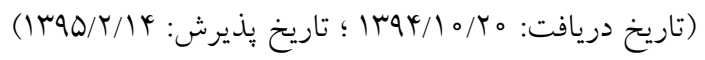

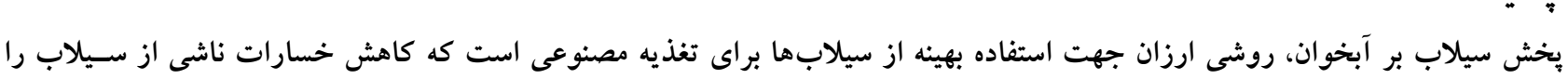

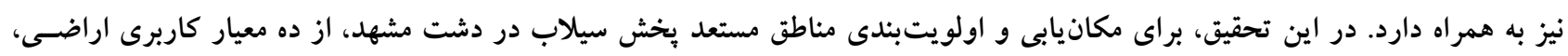

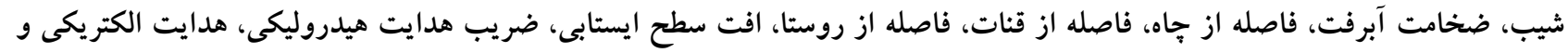

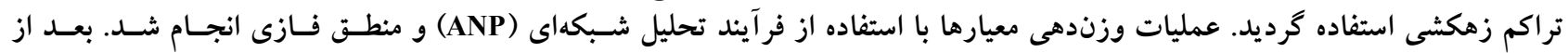

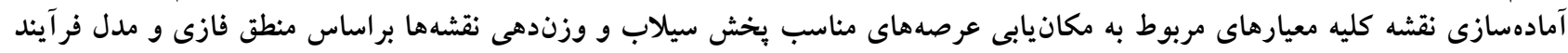

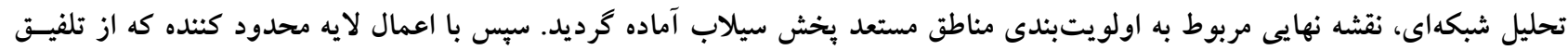

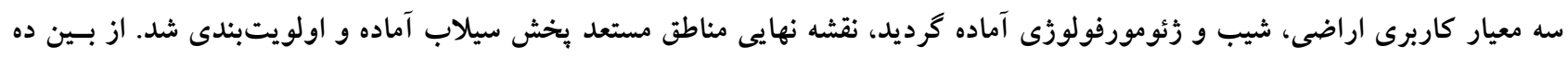

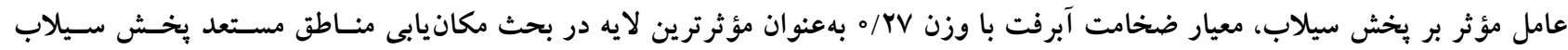

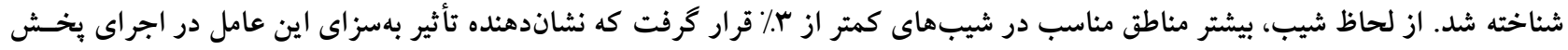

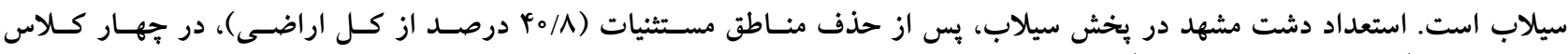

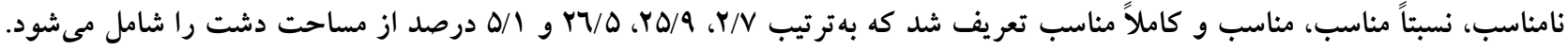

وازههاى كليدى: اولويتبندى، تغذيه مصنوعى، معيار بخش سيلاب، دشت مشهد

1. كروه مرتع و آبخيزدارى، دانشكده منابع طبيعى و كوير شناسى، دانشكاه يزد

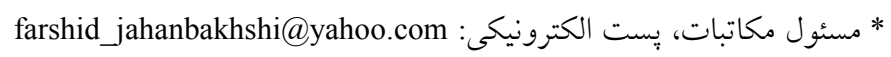


تغذيه مصنوعى آبهاى زيرزمينى بوده است. موهان (11) جهت

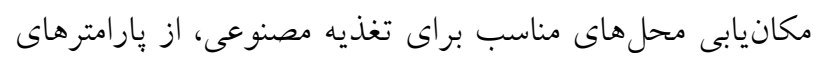

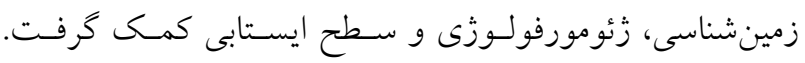

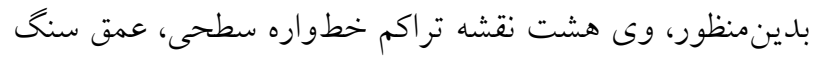

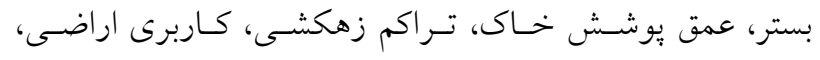

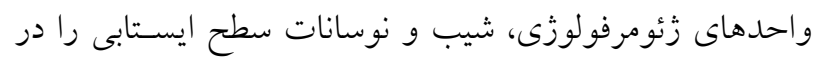

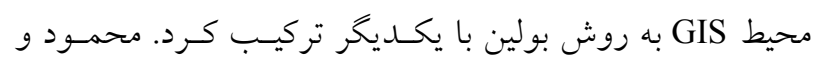

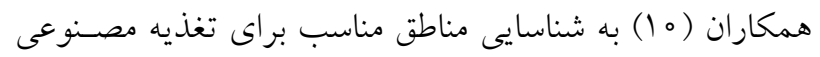

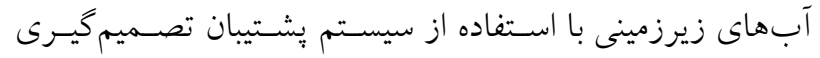

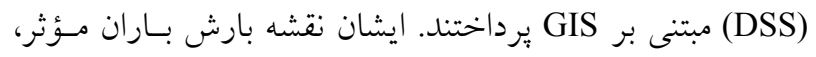

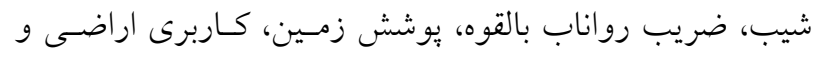

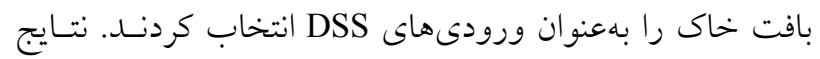

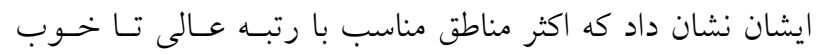

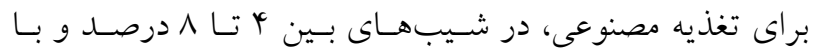

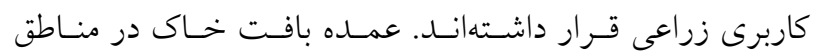

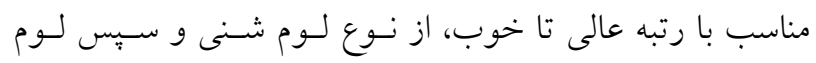

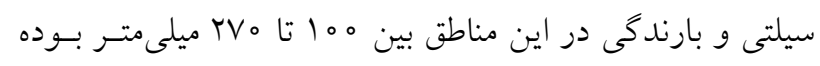

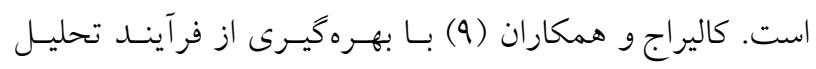

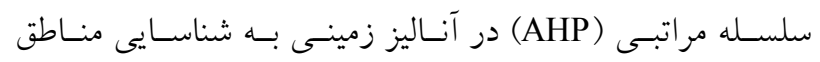

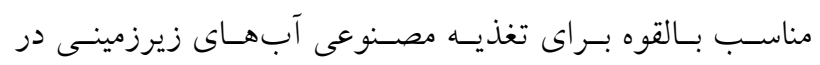

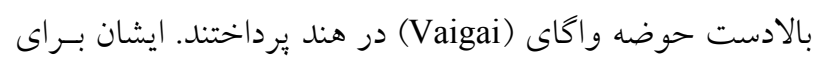

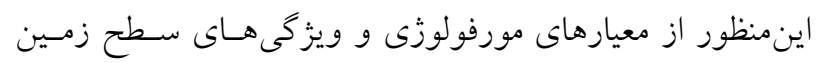

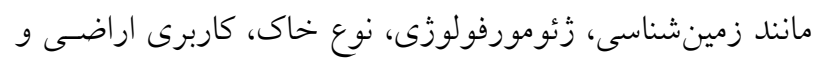

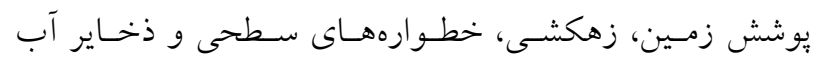

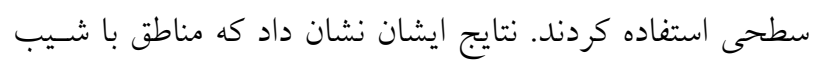

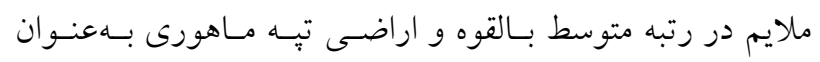

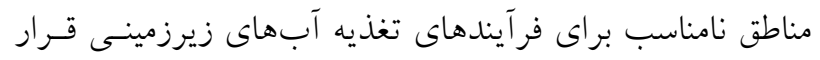

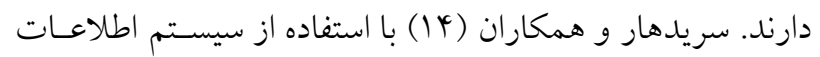

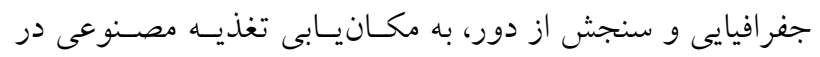

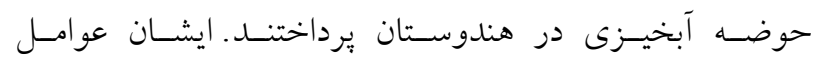

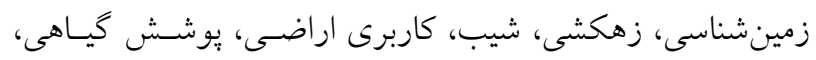

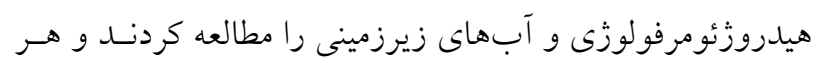

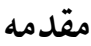

در مناطق خشك و نيمه خشك همانند سـطح عظيمسى از كشـور

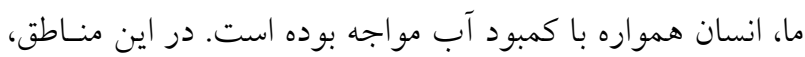

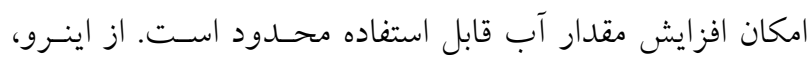

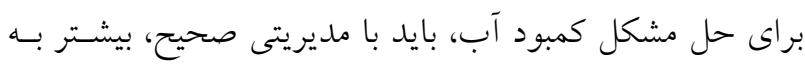

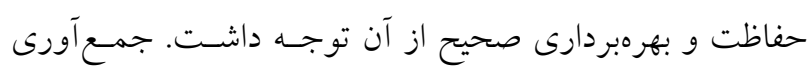

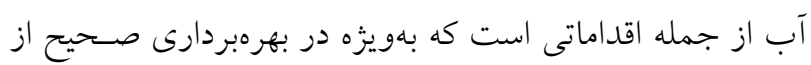
آبهاى موجود در مناطق خشك، مىتواند مؤثر واقع شـود (9).

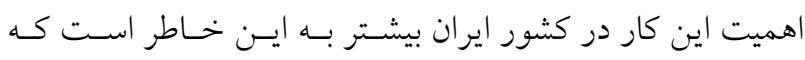

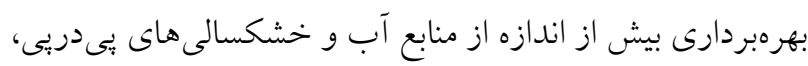

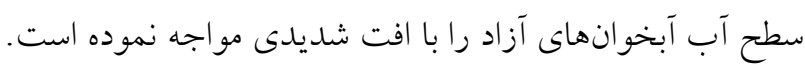

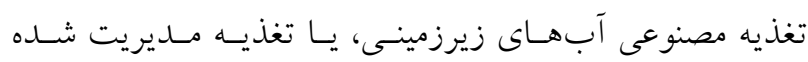

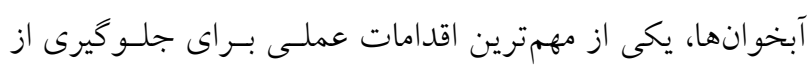

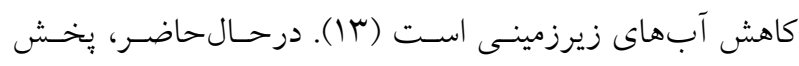

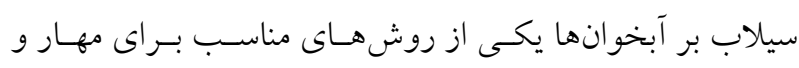

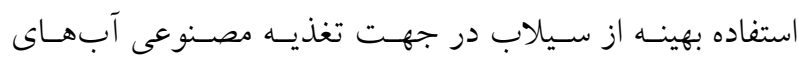
زيرزمينى در مناطق خشك و نيمهخشك بهشمار مىرود. ايسن در

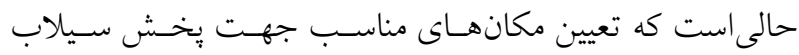

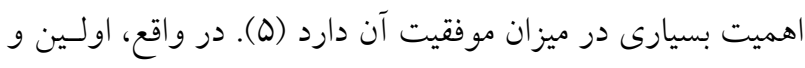

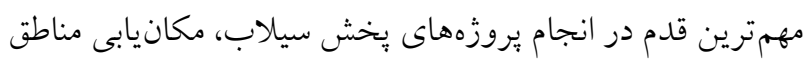

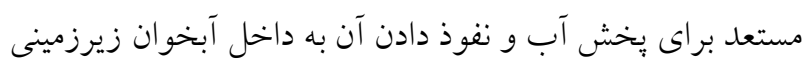

تاكنون تحقيقاتى در خصوص انتخـاب مكــانهـاى مسـتعد

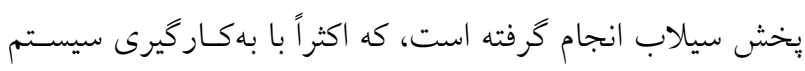

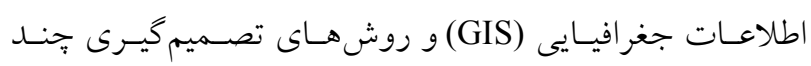

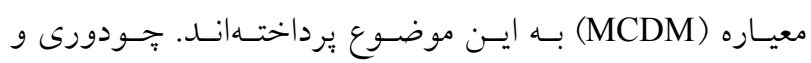

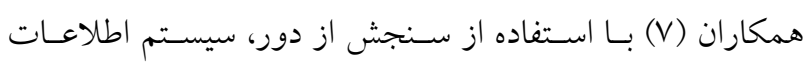

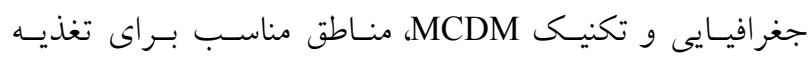

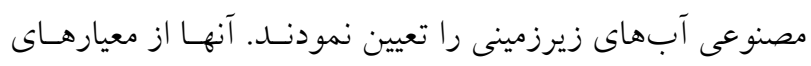

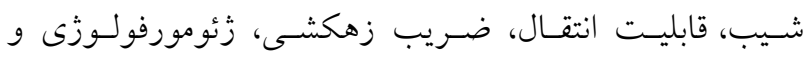

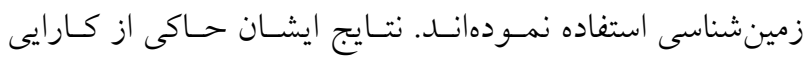

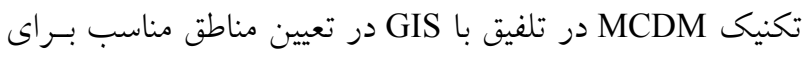


بهوضوح آشكار مى سازد. يزوهش حاضر در صـدد اسـت تـا بـا

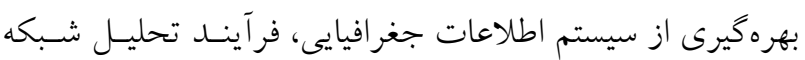
(Analytic Network Process - ANP) دقيـق عرصـهـــاى مناسـب بـراى عمليـات پخـش سـيلاب و

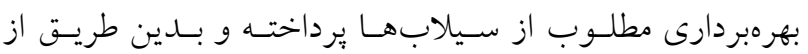
هدررفت آب در اين منطقه جلو كيرى بهعمل آورد.

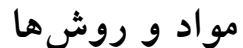

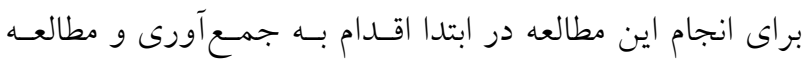

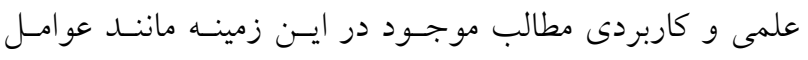

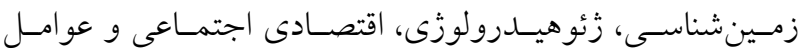

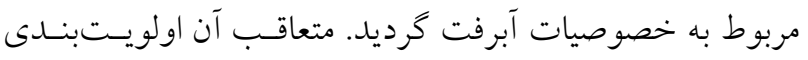
مناطق مناسب جهت تغذيه مصنوعى انجام گرديد. بـــينمنظـور

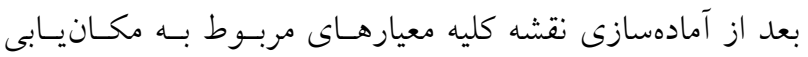
عرصههاى مناسب تغذيه مصنوعى و وزندهى نقشهها براسـاس

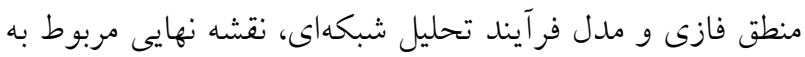

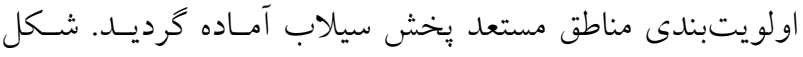
(1) مر احل انجام اين مطالعه را بهطور خلاصه نشان مىدهد.

\section{معرفى منطقه مورد مطالعه}

محدوده دشت مشهل بـا وسـعت 9909 كيلومترمربـع و ارتفـاع

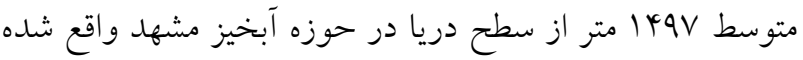
است و شهرستان جناران و بخشى از شهرستانهـاى مشهـد و قوجان را شامل مىشود. اين محدوده در حدفاصـل طـولهـاى

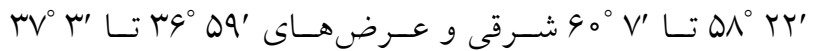

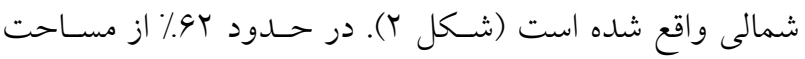

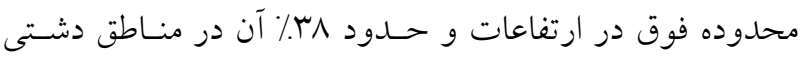

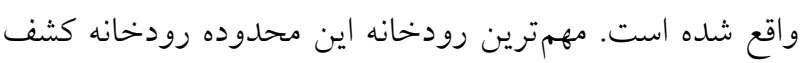

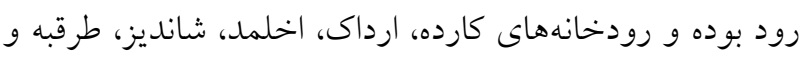

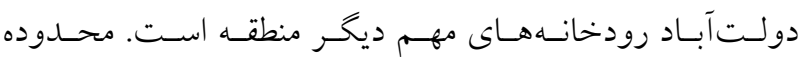

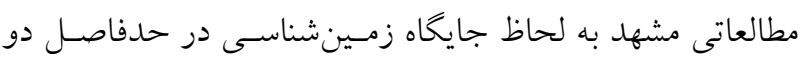

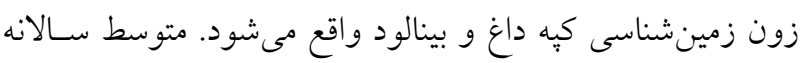

يك از نقشههاى فوق را براساس اهميت آبهــاى زيرزمينسى بـهـ

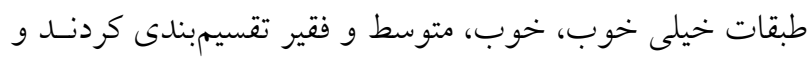

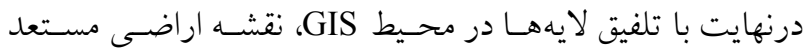

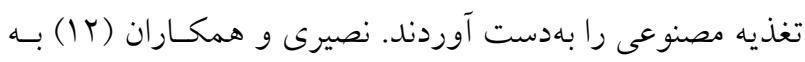
تعيين مناطق مناسب براى مصنوعى تغذيه آبهاى زيرزمينس از

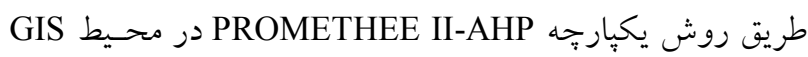

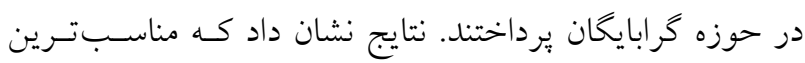

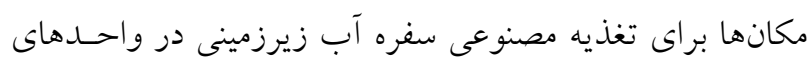

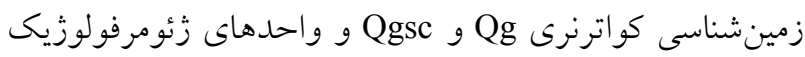

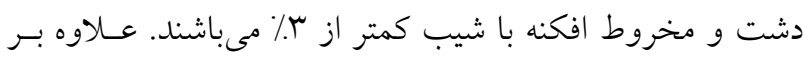
اين، تناظر قابل توجه بين نقشه توليد شده و مناطق كنتـرل، كـهـ

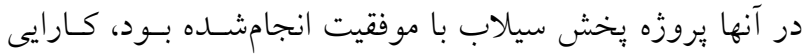

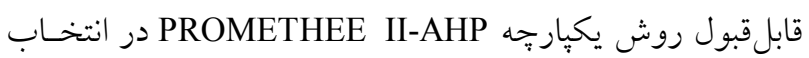
محل مناسب يخش سيلاب را تأييد نمود.

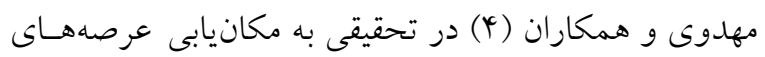

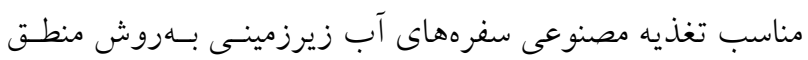

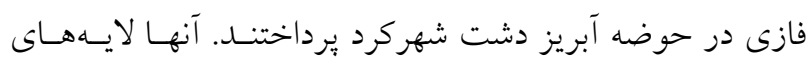
اطلاعاتى مربوط به شيب، نفوذيذيرى سطحى، ضخامت آبرفت،

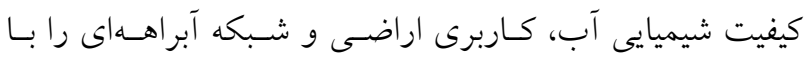

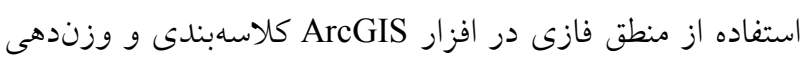

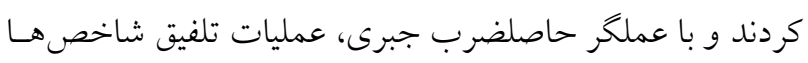

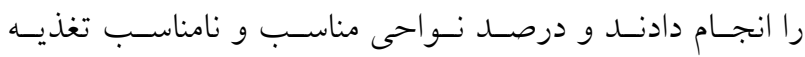

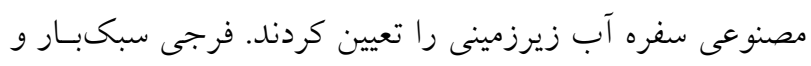

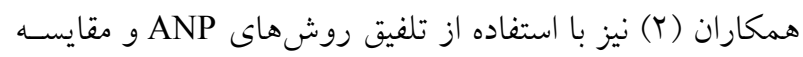
زوجى در محيط GIS به تعيين عرصهاى مناسب بـراى تغذيـهـ

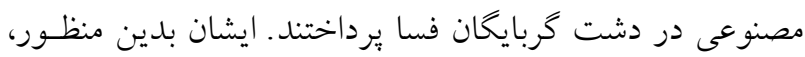

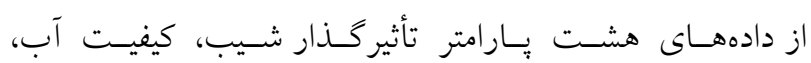

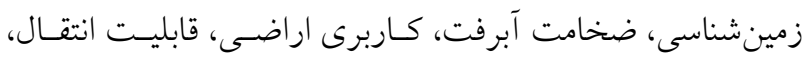
زئومورفولوزى و تراكم زهكشى استفاده نمودند. با توجه به اينكه فعاليتهـاى كشـاورزى در دشـت مشهـهد متكى بر آبهاى زيرزمينى است و همدجنين قرارگيرى اين منطقه در يكى از نواحى خشك كشـور، اهميـت آب رادر ايـن منطقـهـ 


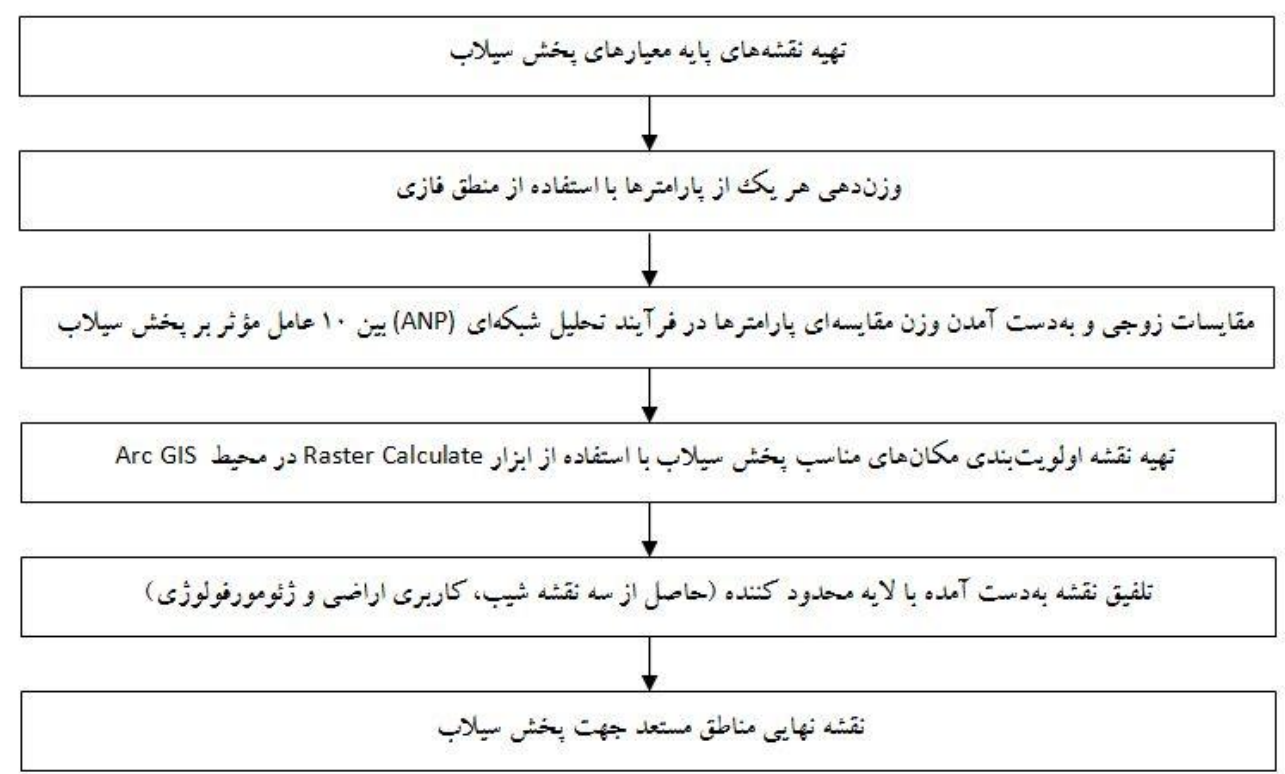

شكل ا. مراحل انجام تحقيق و تهيه نقشه نهايى مناطق مستعد جهت بخش سيلاب

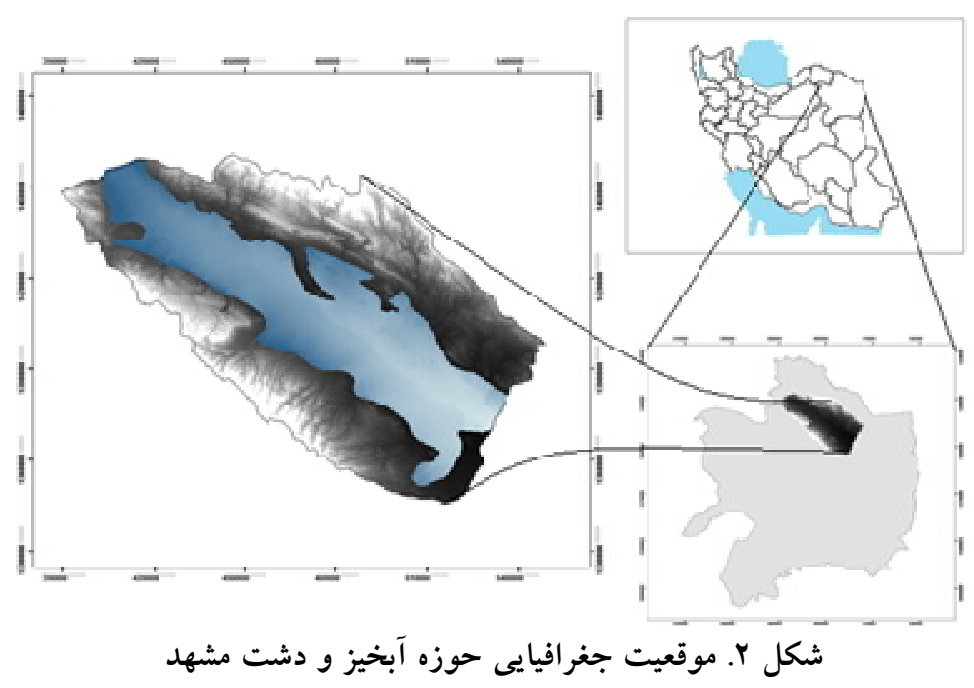

ده معيار كاربرى اراضى، شيب، ضخامت آبرفت، فاصله از جــاه،

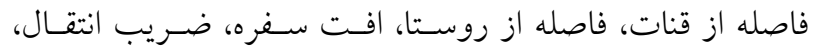
هدايت الكتريكى (EC)، و تراكم زهكشى استفاده خرديد.

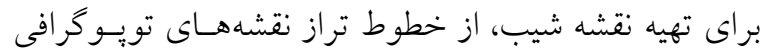

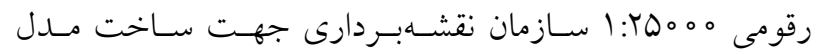
رقومى ارتفاع استفاده شد و از روى نقشه مدل رقـومى ارتفـاع،

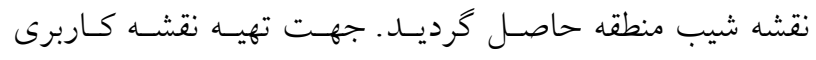

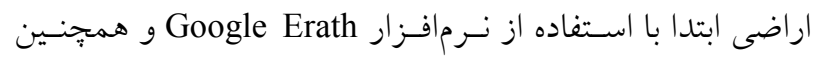

دماى روزانه منطقه مورد مطالعه در ارتفاعات و دشت بهترتيـب

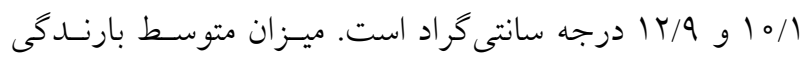

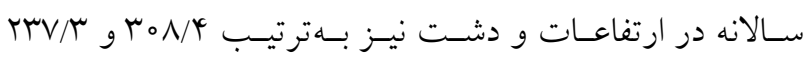

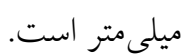

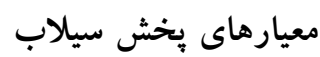
در اين يثزوهش با استفاده از مطالعـات بيشـين و نظـر خبركـان

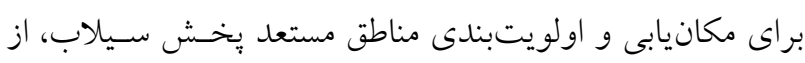


مشاهداتى دشت مشهد استفاده شد. براى اينمنظـور از متوسط

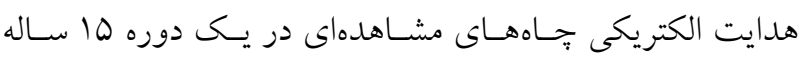

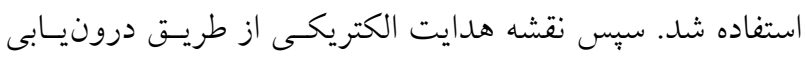

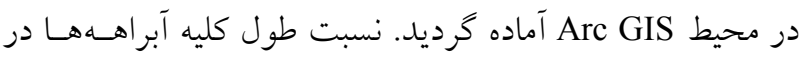

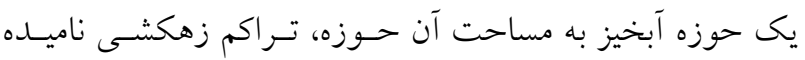

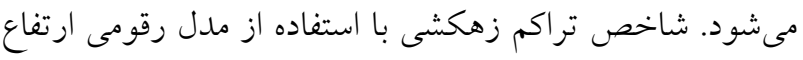
حوزه و نرم|فزار Arc SWAT تهيه كرديد.

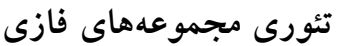

تئورى فازى در سال 1990 توسط لطفىزاده در مقالهاى با عنوان

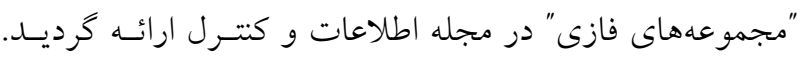

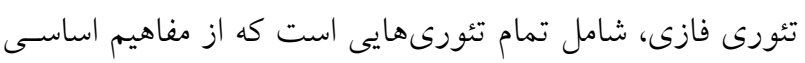

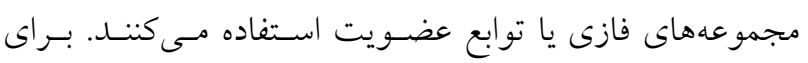

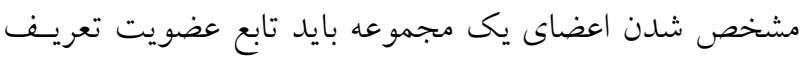

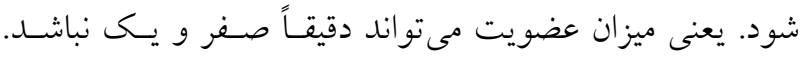

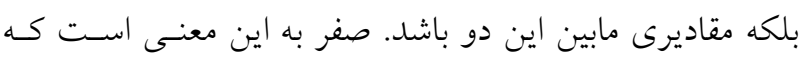

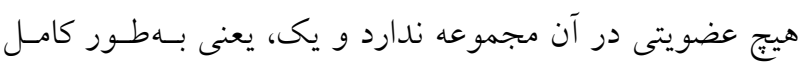

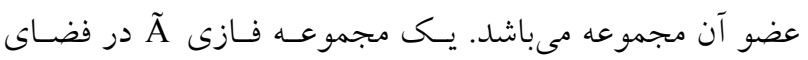

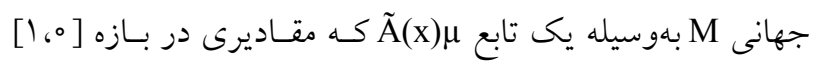

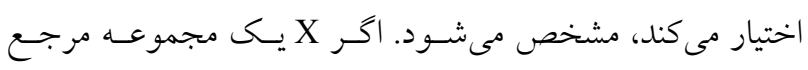

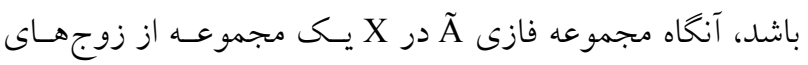

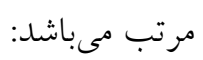

\section{$\tilde{\mathrm{A}}=[((\chi, \mu \tilde{\mathrm{A}}(\chi)) \mid \chi \in X)]$}

كه (X)

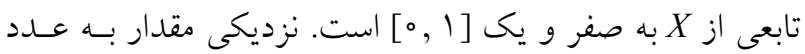
يك نشاندهنده تعلق بيشتر x به مجموعه Ã مىباشد. در حسالتى كه x كاملاً در Ã باشد، داريم:

$\mu(\chi)=\tilde{A})$

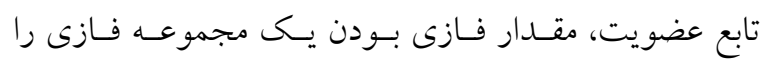

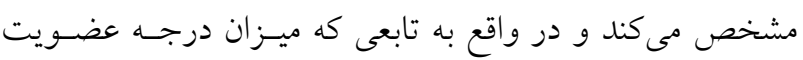

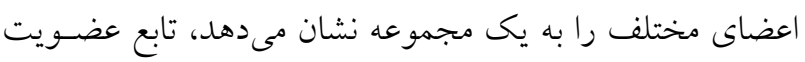

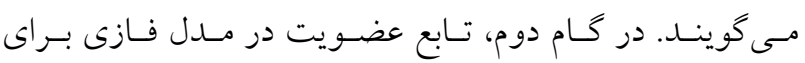

بازديدهاى ميدانى محدوده كاربرى دشت مشهـ مشـخص شــ. سبس با استفاده از نرمافزار كمكى Global mapper اطلاعات به مهنه محيط نرمافزار ArcGIS منتقل و نقشه رقـومى كـاربرى اراضسى

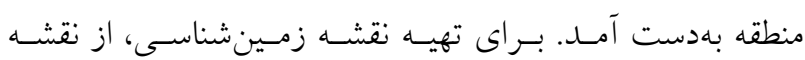
هo

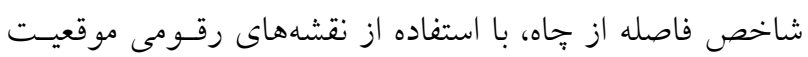

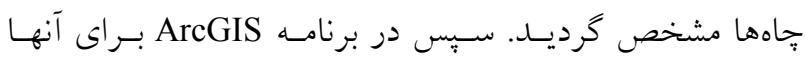

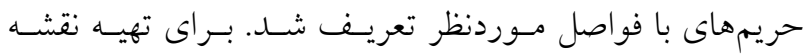

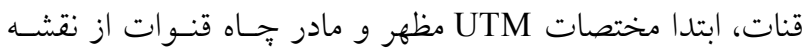

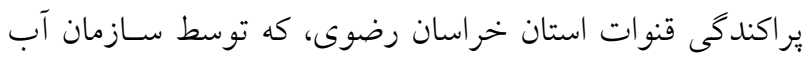

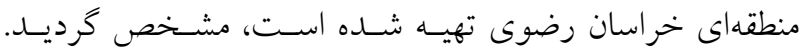

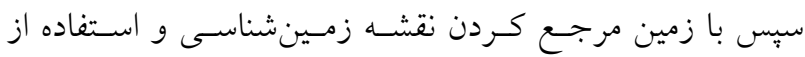

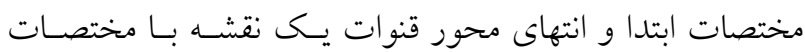

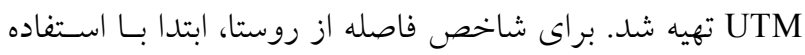

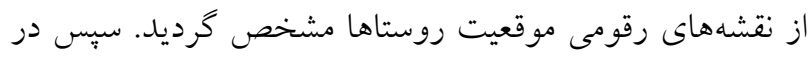

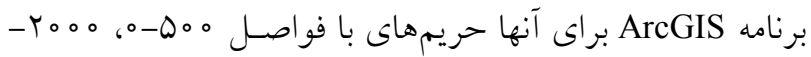

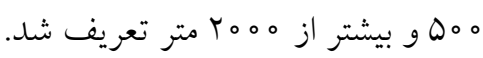

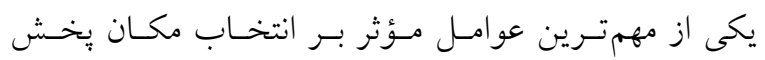

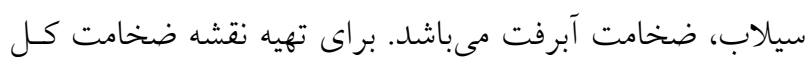

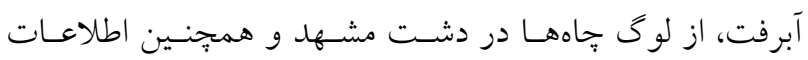

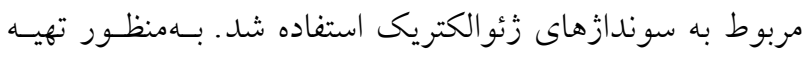

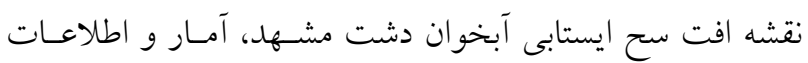

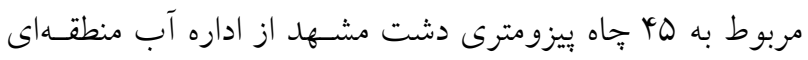

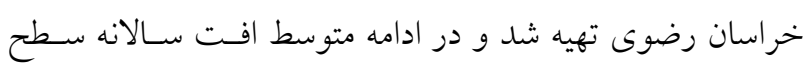

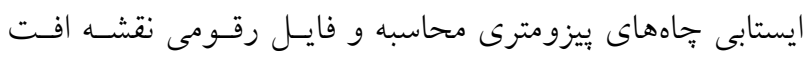

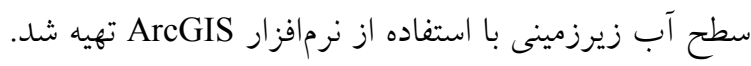

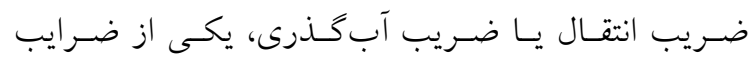

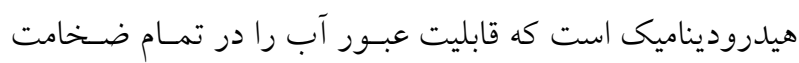

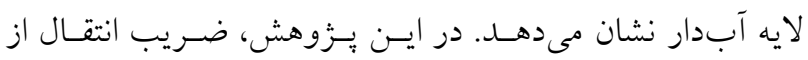

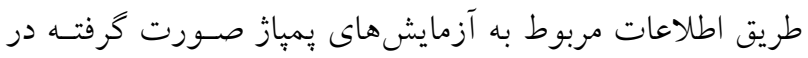

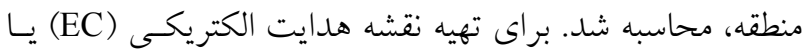

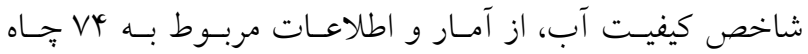


و ميان خوشهها امكانيذير است. فر آيند تحليل شبكهاى (ANP) را در سه مرحله زير مىتوان خلاصه كرد:

مرحله اول: انتخاب هدف و تعيين معيارها و شاخصهاى استاندارد

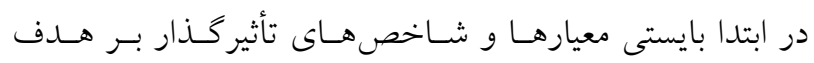

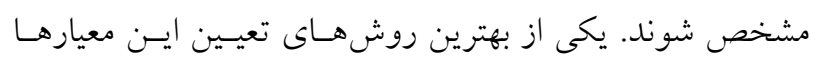

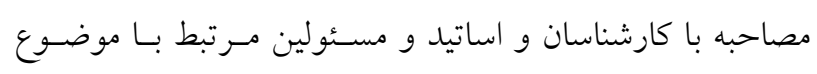

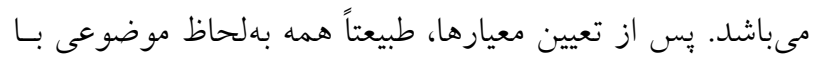

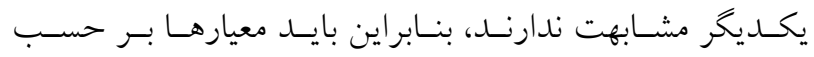

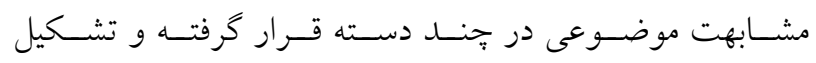

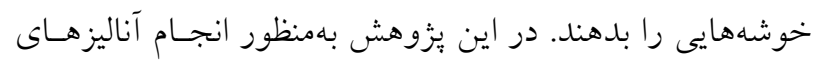

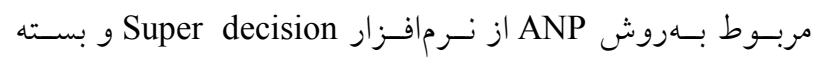

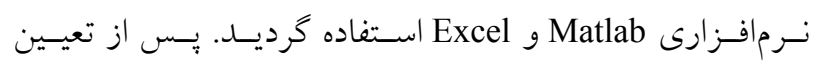
Super معيارها، عناصر و كزينهها، خوشهبندى به كمى نرمائه decision

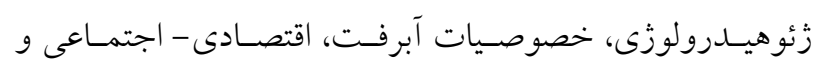

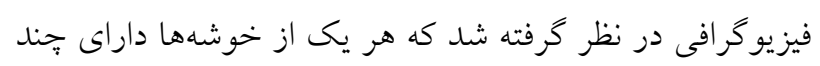
معيار هستند (شكل r) مرئ

\section{مرحله دوم: تعيين روابط، اثرات و ارتباطات بين خوشـههـا، عناصر و گزينهها}

در اين مرحله، اقدام به تعيين و شناسايى روابط بين خوشههـا و و وداص

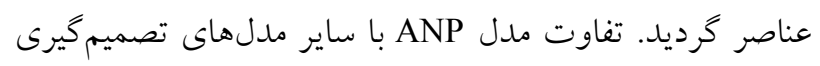

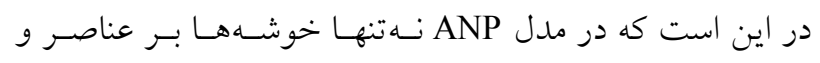

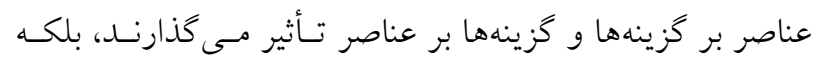

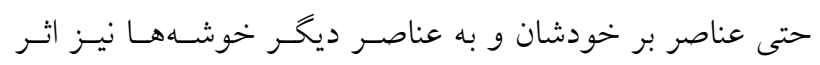

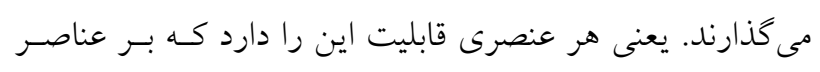

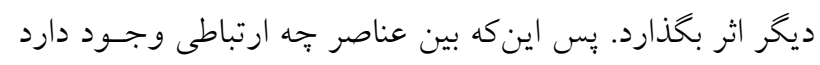

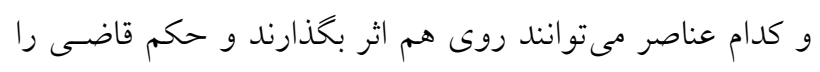

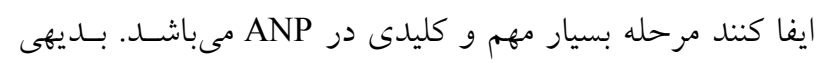

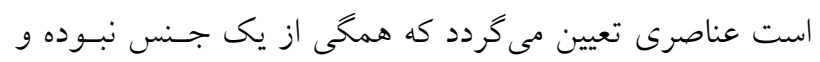

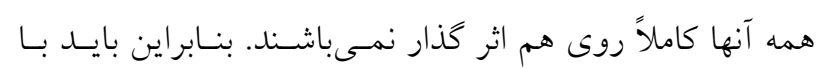

فاكتورهاى مورد نظر بهصـورت غيرخطى درنظـر كرفتـهـ شـد.

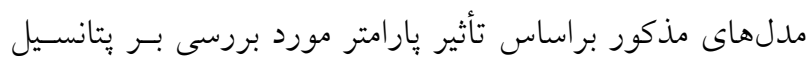

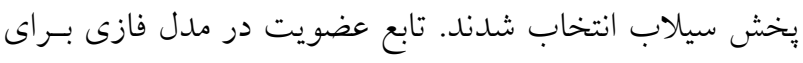

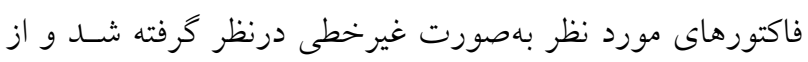

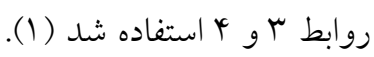
$\mu(x)=\left\{\begin{array}{l}1, x \leq a \\ 1-r\left(\frac{x-a}{b-a}\right)^{r}, a<x \leq \frac{a+b}{r} \\ r\left(b-\frac{x}{b-a}\right)^{r}, \frac{a+b}{r}<x<b \\ 0, x \geq b\end{array}\right\}$

$\mu(x)=\left\{\begin{array}{l}\cdot, x \leq a \\ 1-r\left(\frac{x-a}{b-a}\right)^{r}, a<x \leq \frac{a+b}{r} \\ r\left(b-\frac{x}{b-a}\right)^{r}, \frac{a+b}{r}<x<b \\ 1, x \geq b\end{array}\right\}$

نقشههاى شـيب، ضـريب انتقـال، EC، افـت سـفره، تـراكم

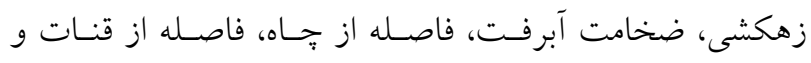

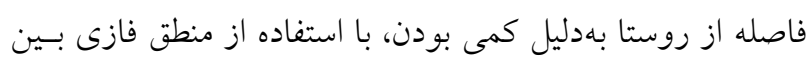

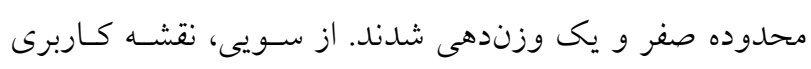

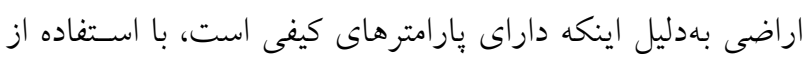

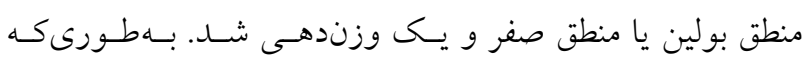

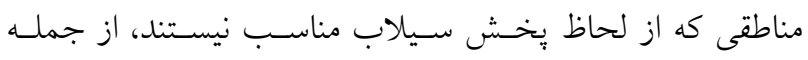

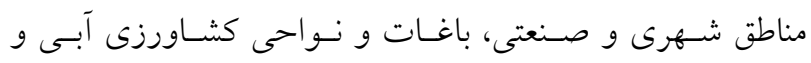

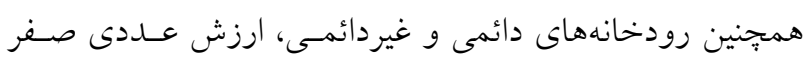

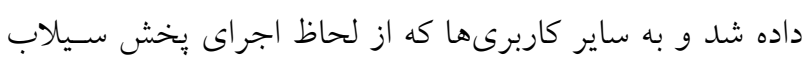
مناسب هستند، ارزش عددى يك داده شد.

\section{فر آيند تحليل شبكهاى (ANP) و مراحل آن} فرآيند تحليل شبكهاى (ANP) هر موضوع و مسئلهاى را به مثابـه

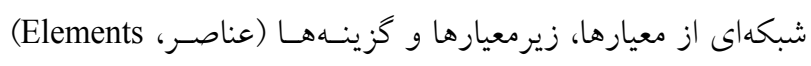

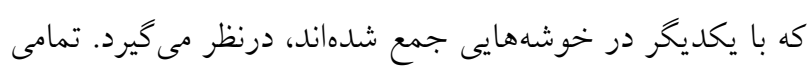
عناصر در يك شبكه مىتوانند بههرشكل، داراى ارتباط با يكديخر

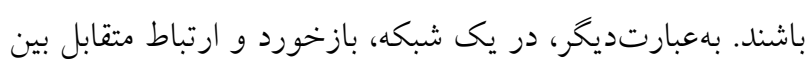




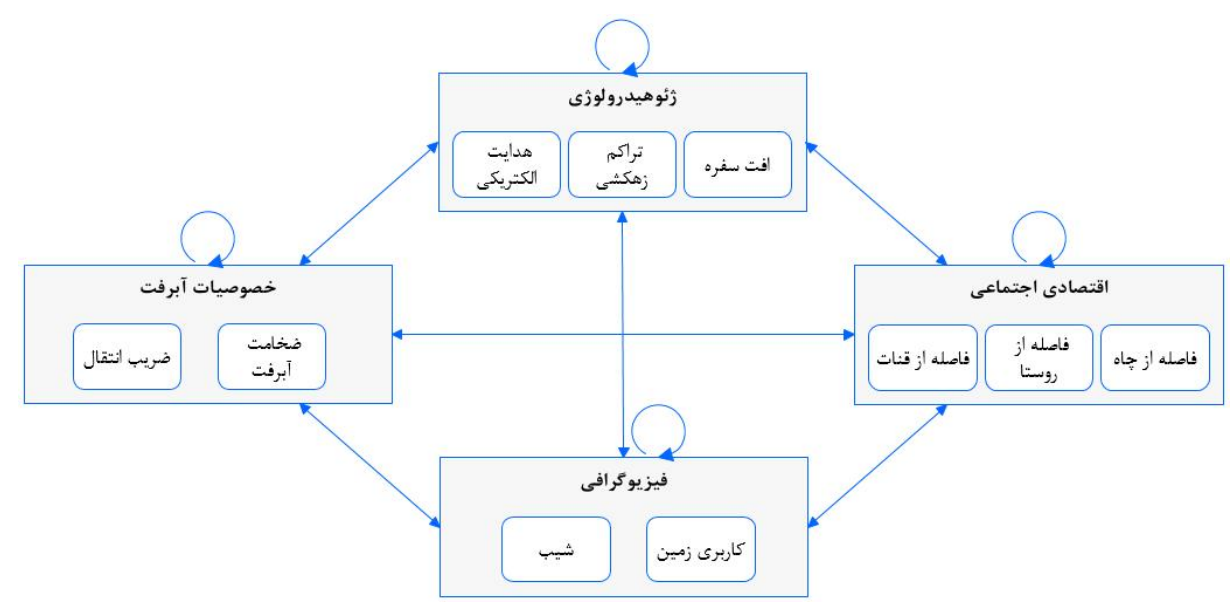

شكل r. خوشهها و معيارهاى استفاده شده در تحقيق

منطق بولين وزن صفر و يك داده شد. وزن نهايى هـر كـدام از

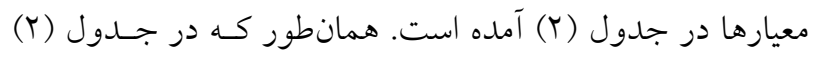
مشاهده مىشود، پِ از انجام مقايسات زوجى در فرآيند تحليل

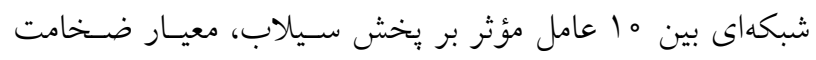

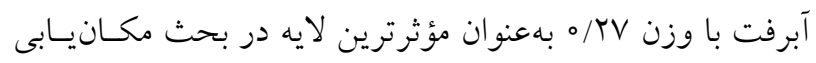

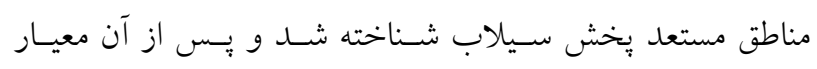

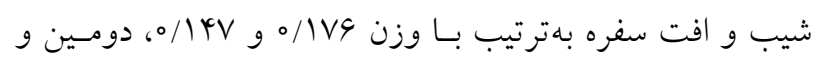

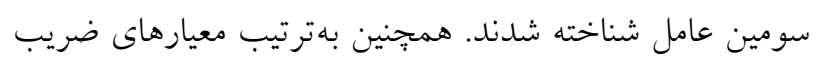

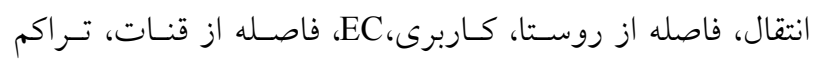

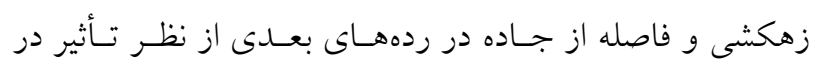
مكانيابى بخش سيلاب قرار دارند.

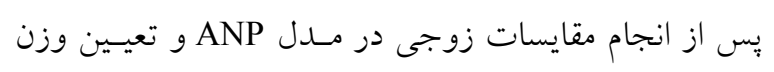

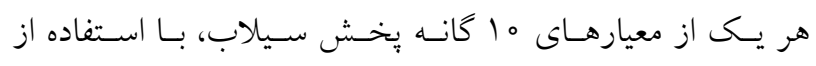

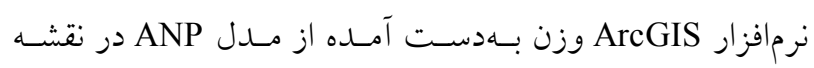

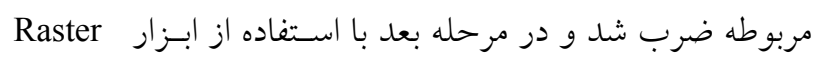

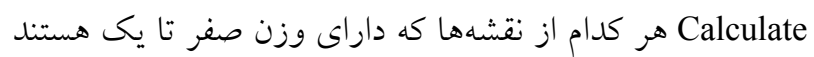

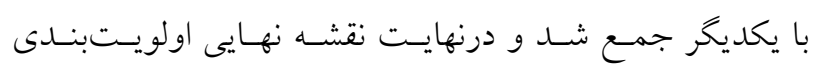

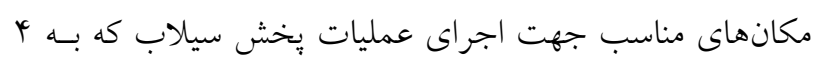

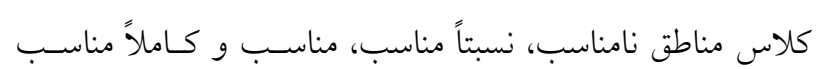
تقسيم شده است، تهيه گرديد (شكل ها ه).

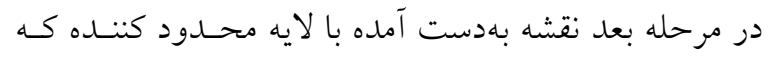

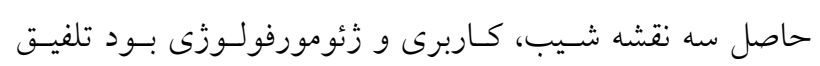

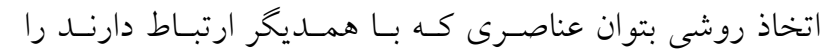
شناخت تا از طريق اين ارتباطات، مقايسـات زوجسى بـين آنها

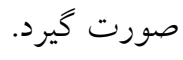

مرحله سوم: مقايسه زوجى بين عناصر، خوشهها و گزينهها و

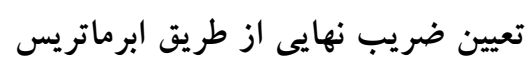

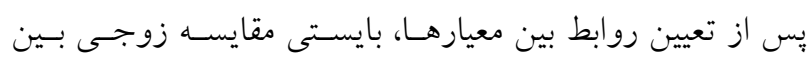

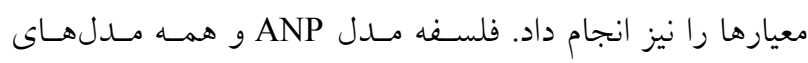
تصميم گيرى اين است كه همه معيارها از نظر ميزان اهميتى كـهـ

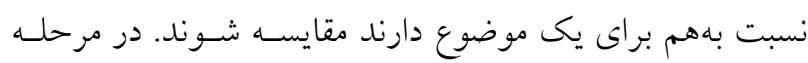

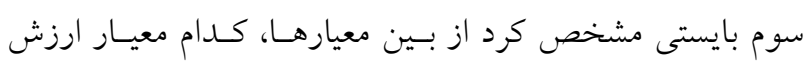

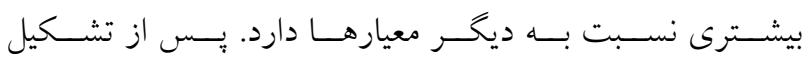

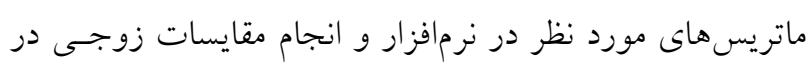

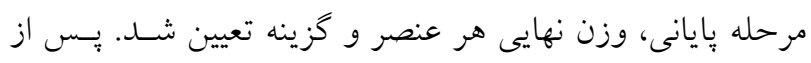

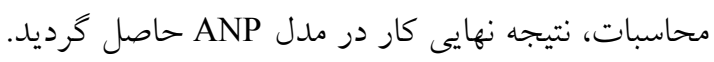

\section{نتايج و بحث}

شكل (Y) نقشـهــاى مـورد اسـتفاده در ايسن مطالعـه را نشـان

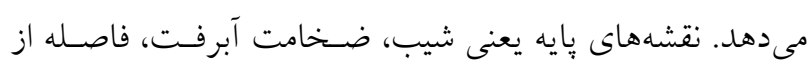

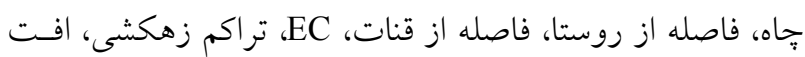

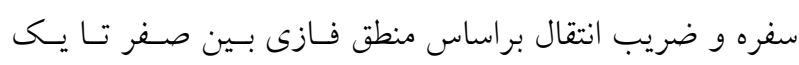

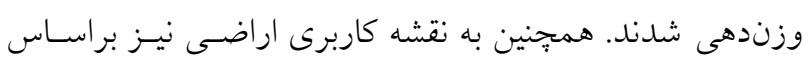



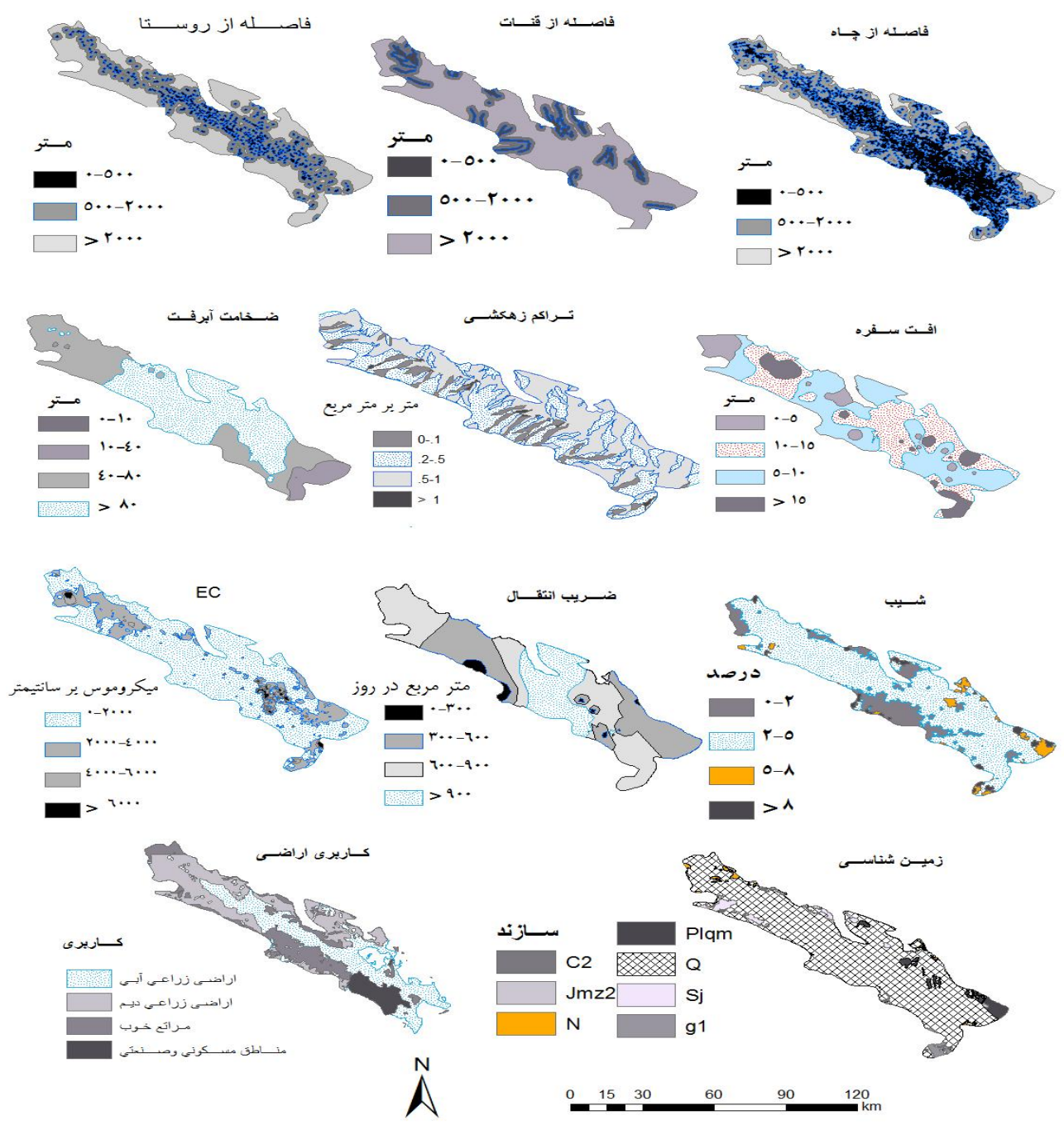

شكل f. نمايش نقشههاى مورد استفاده در تحقيق

جدول r. وزن نهايى معيارهاى • ا كانه با استفاده از نرمافزار Super Decision

\begin{tabular}{|c|c|c|c|}
\hline وزن نهايى & وزن عمومى & معيار & خوشه \\
\hline 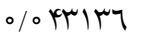 & $\circ / T \circ Y \circ D$ & هدايت الكتريكى (EC) & \multirow{3}{*}{ زئوهيدرولوزى } \\
\hline -/MVIAK & ./797rr & افت سفره & \\
\hline$\circ / \circ Y 1 \circ \Lambda$ & $.099 V Y$ & تراكم زهكشى & \\
\hline ./IV777r & $\circ / V Y \wedge 97$ & شيب & \multirow{2}{*}{ فيزيو گرافى } \\
\hline.$/ 070 T A V$ & $\circ / Y V I \circ Y^{4}$ & كاربرى & \\
\hline o/TVVVTY & - /77k4P & ضخامت آبرفت & \multirow{2}{*}{ خصوصيات آبرفت } \\
\hline - IY F YOA & - MTDQR & ضريب انتقال & \\
\hline - OVDTTQ & $\circ / 0 \wedge 9 \vee 7$ & فاصله از روستا & \multirow{3}{*}{ اقتصادى اجتماعى } \\
\hline $0 / 0411 \Delta V$ & $\circ / M T \circ 9 \Lambda$ & فاصله از قنات & \\
\hline $0 / 011 k 4 q$ & $\circ / \circ \wedge 9 Y \wedge$ & فاصله از پاه & \\
\hline
\end{tabular}




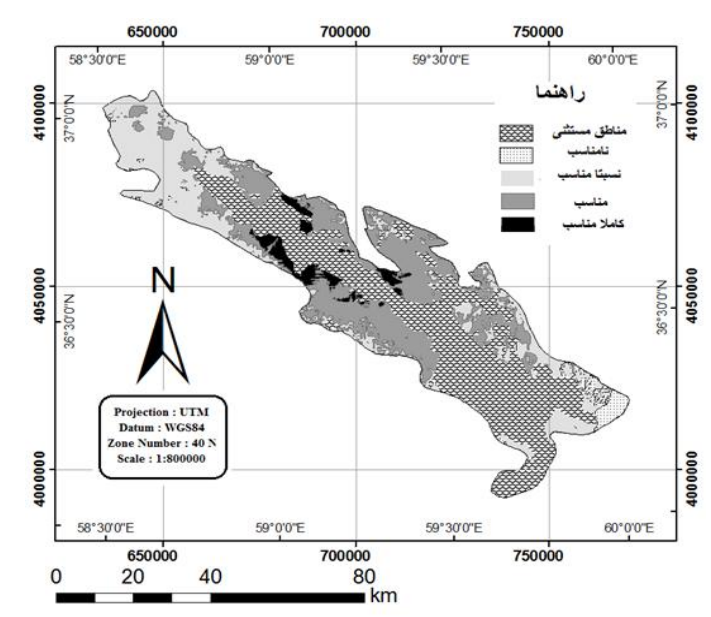

شكل 9. نقشه مكانيابى بخش سيلاب همراه با اعمال لايه محدود كننده

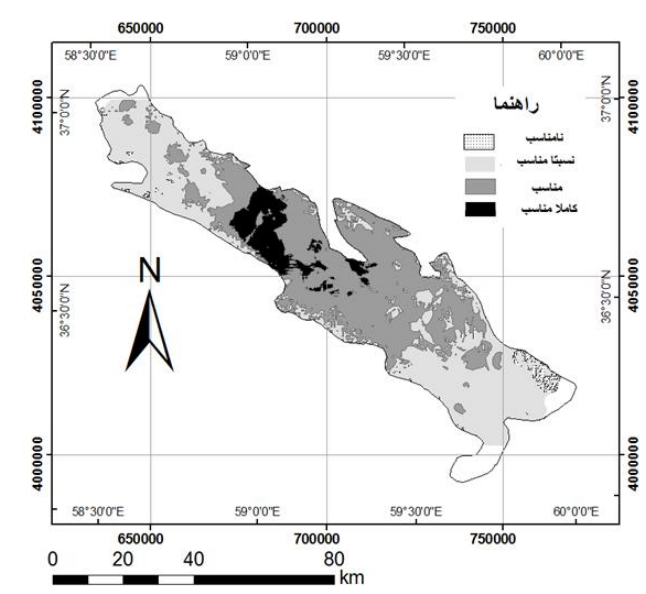

شكل ه. نقشه مكانيابى بخش سيلاب بدون اعمال لايه محدودكنتده

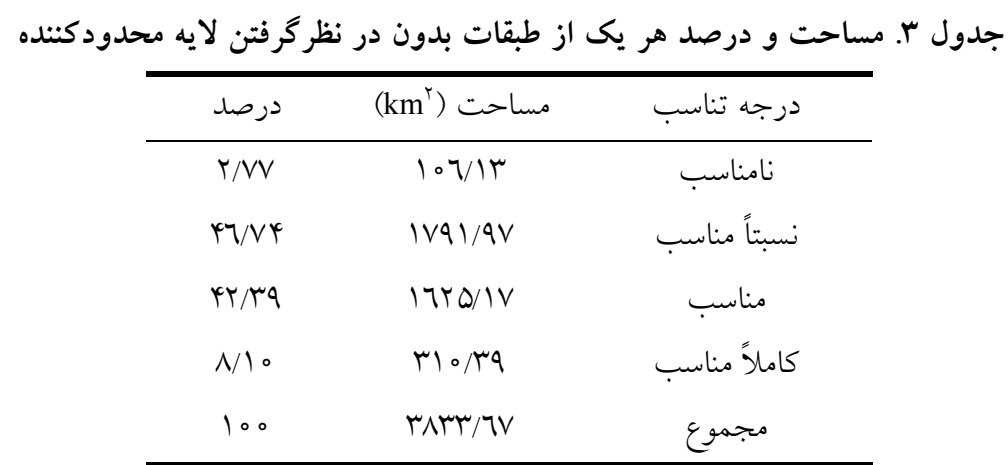

\begin{tabular}{|c|c|c|}
\hline درصد & مساحت ( & درجه تناسب \\
\hline T/NY & $104 / 09$ & نامناسب \\
\hline TQ/QT & $99 r / 9 r$ & نسبتاً مناسب \\
\hline$r Y / D 1$ & $1017 / \mu 1$ & مناسب \\
\hline$r / \circ q$ & $107 / 4$ & كاملاً مناسب \\
\hline$\varphi \circ / V T$ & $107 Y / 77$ & مستثنيات \\
\hline 100 & זیM/TV & مجموع \\
\hline
\end{tabular}

شدند (Y). درنهايت نقشه نهـايى منـاطق مسـتعد جهـت بخـش

$$
\text { سيلاب تهيه كرديد (شكل 9) }
$$

جدول (r) مساحت و درصـد هـر يـك از طبقـات تناسـب

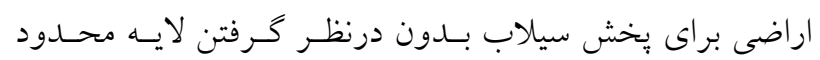

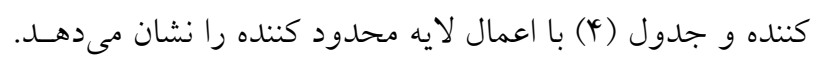

كرديد. در نقشه بهدست آمده از مرحله قبـل منـاطقى كـه داراى

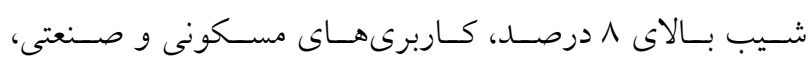
كشاورزى آبى و مناطق كوهستانى بودند بهعنـوان لايسه محـدود

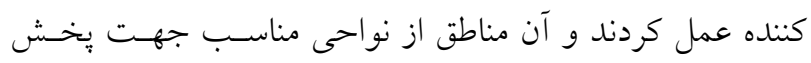
سيلاب حذف كرديده و بهعنوان منـاطق مسـتثنا درنظـر كرفتـه 
دشت و مخروط افكنه با شيب كمتر از ب/ تشخيص دادند. در اين تحقيق، بهمنظـور تعيـين وزن هركـدام از معيارهـاى بخش سيلاب از فرآيند تحليل شبكهاى (ANP) استفاده كرديـد. در مدل تحليل شبكهاى بهدليل اينكه در يك شبكه، بـازخورد و ارتباط متقابل بين و ميان خوشهها امكـانيـذير اسـت، از اينـرو نتايج حاصل از مدل ANP حـاكى از قابـلقبـول بـودن مــل و همجينين دقت بالاى مدل است كه با نتـايج فرجسى سـبكبـار و همكاران (0) مبنى بر قابليت و دقت بـالا در بـهــاركيرى مــل جهت تعيين مناطق مناسب بخش سيلاب همسو مىباشد. ANP هر قدر تعداد لايههاى اطلاعاتى در داخل مدل افزايش يابد، دقت ملدل بيشتر خواهد شد.

\section{نتيجه گيرى}

يخخش سيلاب بر آبخوان، روشى ارزان جهـت اسـتفاده بهينـهـ از

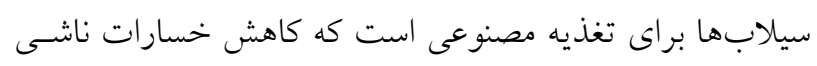
از سيلاب را نيز بههمراه دارد. در اين تحقيق، براى مكانيـابى و

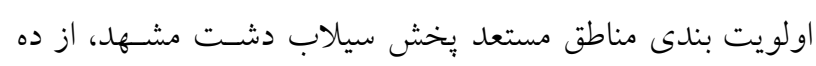

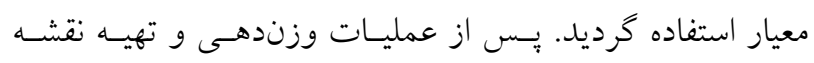

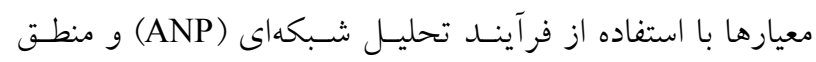
فازى، نقشه مربوط به اولويتبندى مناطق مستعد بِخش سيلاب

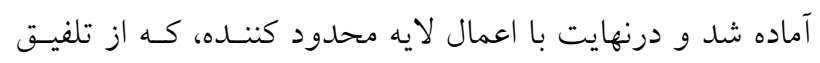

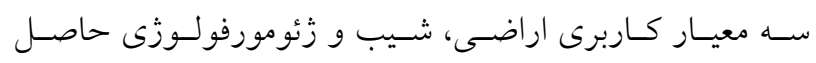

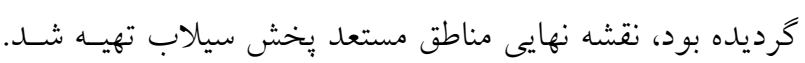

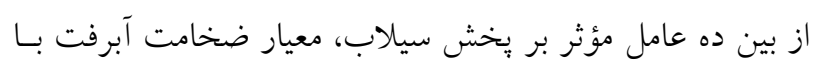

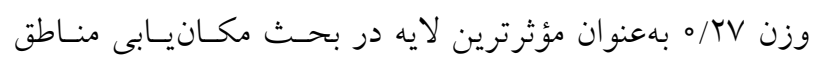

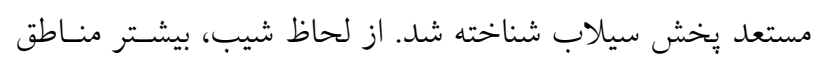
مناسب در شيبهاى كمتر از ب/٪ قرار گرفت كه نشاندهنده تـأثير بهسزاى اين عامل در اجراى بخخش سـيلاب مسىباشـــ اسـتعداد دشت مشهل در يخش سيلابُ، بِ از حذف منـاطق مستشنيات

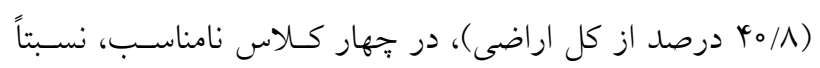
مناسب، مناسب و كاملاً مناسب تعريف شد كـه بـهـترتيـب T/V،

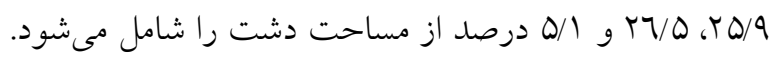

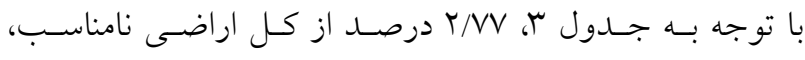

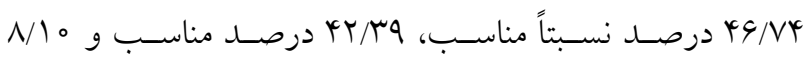
درصد كاملاً مناسـب، جهـت اجــراى عمليـات يخـش سـيلاب شناخته شد. در مرحله بعد نقشه حاصله بـا لايسه محدودكنتـده،

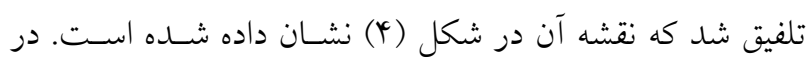

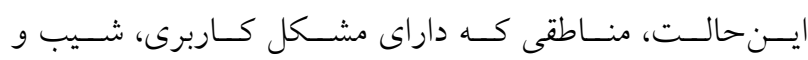

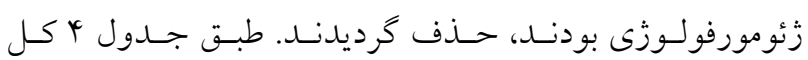

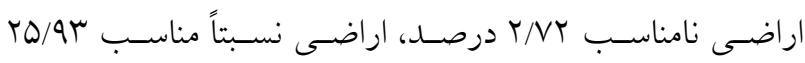

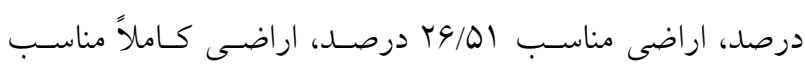

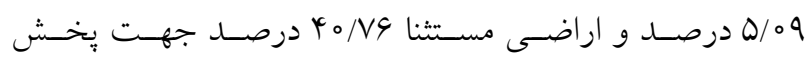
سيلاب تشخيص داده شد. با مقايسه جداول (r) و (Y) نتيجه كيرى مى شود كـه درصـد تناسب اراضى بعد از اعمال لايه محدود كننده تقريباً بـهـ نصـف مىرسد. مهدوى و همكاران (Y) نيز در مكانيابى بخش سيلاب در حوزه آبخيز شهركرد، بهاين نتيجه رسيدند كه درصد تناسـب

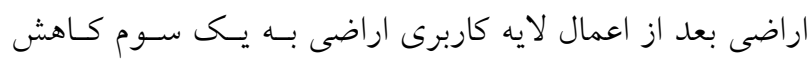
يافته است. از لحاظ شيب، بيشتر مناطق مناسب در شيبهـاى كمتـر از ب درصد قرار گرفته است كه نشاندهنده تأثير بهسزاى اين عامل در اجراى بخش سيلاب مىباشـــ ايسن مســـله در تحقيقـات قرمـز

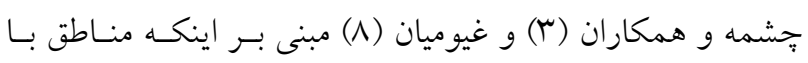
شيب كمتر از ه. جهت بخش سيلاب مناسـب مسىباشـند، بيـان كرديده است. از لحاظ زمينشناسى، مناطق مسـتعد بخخـش سـيلاب بيشـتر در

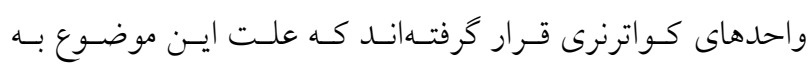
نقوذيذيرى بالا و شيب مناسب ايسن سـازند جهــت اجـراى يخــش سيلاب برمى گردد. ايسن نتـايج بـا يافتـهــاى فرجسى سـبكبـار و همكاران (Y) كه حدود نيمى ازسطح مورد مطالعه كه براى عمليـات تخش سيلاب مناسب بودند را در عرصههاى كـو اترنرى مكـانيـابى

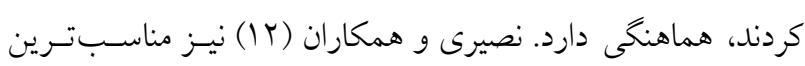

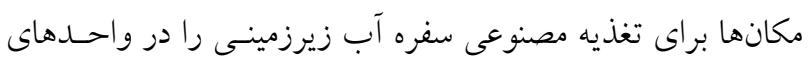

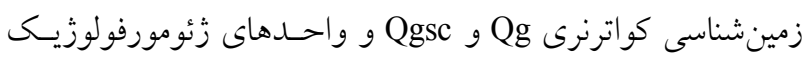




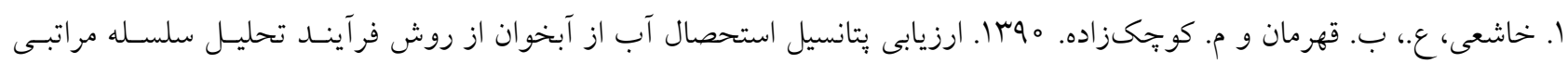

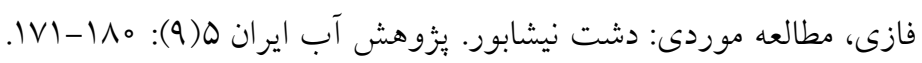

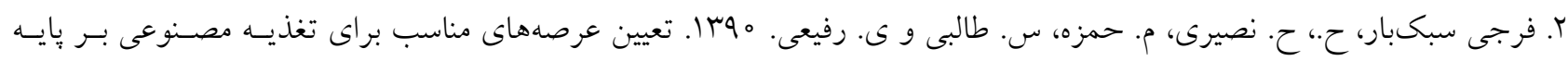

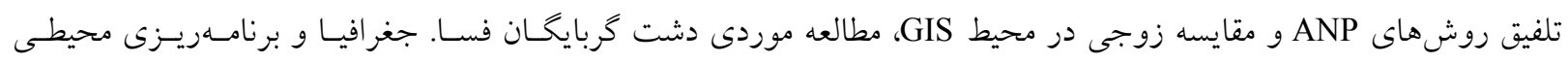

$.14-177:(Y) Y r$

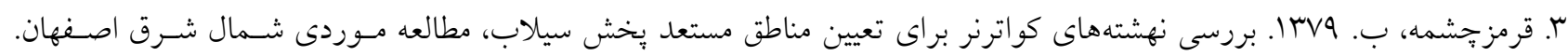
پاياننامه كارشناسى ارشد مهندسى منابع طبيعى، دانشكدة منابع طبيعى، دانشخاه تهران.

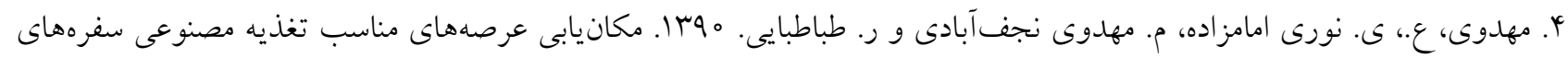

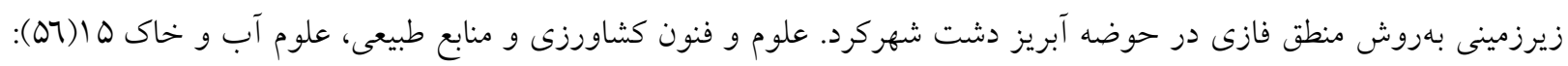

$.7 \mu-V \Lambda$

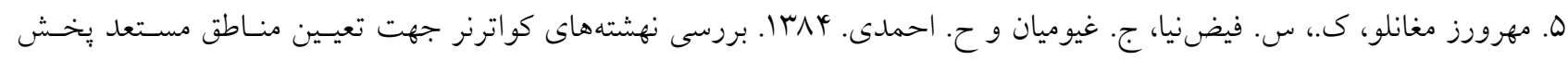

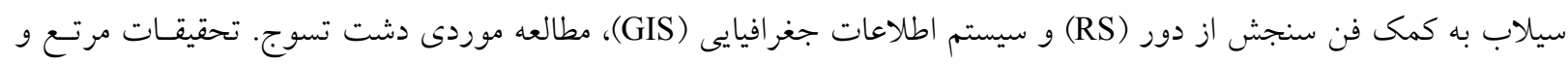
بيابان ايران r Y ITV-MTV

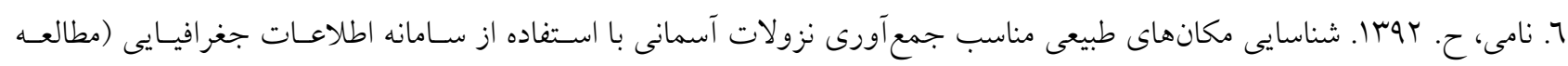

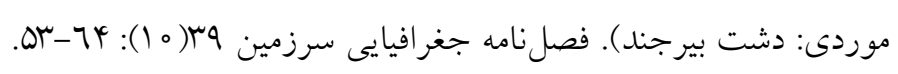

7. Chowdhury, A., M. K. Jaha and V. M. Chowdary. 2010. Delineation of groundwater recharge zones and identification of artificial recharge sites in West Medinipur district, West Bengal, using RS \& GIS and MCDM techniques. J. Environ. Earth Sci. 59: 1209-1222.

8. Ghayoumian, J., M. Mohseni Saravi, S. Feiznia, B. Nouri and A. Malekian. 2007. Application of GIS techniques to determine areas most suitable for artificial ground water recharge in a coastal aquifer in southern Iran. J. Asian Earth Sci. 30(2): 364-374.

9. Kaliraj, S., N. Chandrasekar and N. S. Magesh. 2014. Identification of potential groundwater recharge zones in Vaigai upper basin, Tamil Nadu, using GIS-based analytical hierarchical process (AHP) technique. Arab. J. Geosci. 7: 1385-1401.

10. Mahmoud, S. H., A. A. Alazba and M. T. Amin. 2014. Identification of potential sites for groundwater recharge using a GIS-based decision support system in Jazan Region-Saudi Arabia. J. Water Resource Manage. 28: 33193340 .

11. Mohan, G. and M. N. Ravi Shankar. 2005. A GIS-based hydrogeomorphic approach for identification of sitespecific artificial-recharge techniques in the Deccan Volcanic Province. J. Earth Sys. Sci. 114(5): 505-514.

12. Nasiri, H., A. D. Boloorani, H. A. Faraji Sabokbar, H. R. Jafari, M. Hamzeh and Y. Rafii. 2013. Determining the most suitable areas for artificial groundwater recharge via an integrated PROMETHEE II-AHP method in GIS environment (case study: Garabaygan Basin, Iran). J. Environ. Monit. Assess. 185: 707-718.

13. Poveda, B. 2008. Farmland appraisal based on the analytic network process. J. Glob. Optim. 42: 143-155.

14. Sreedhar Ganapuram, G. T., I. V. Vijaya Kumar and M. Murali Krishna. 2009. Mapping of ground water potential zone in the Musi basin using remote sensing data and GIS. J. Adv. Eng. Software 40(7): 506-518. 


\title{
Investigating Suitable Areas for Flood Spreading Using Fuzzy Logic and Analytic Network Process (ANP) (Case Study: Mashhad Plain)
}

\author{
E. Zahedi, F. Jahanbakhshi and A. Talebi ${ }^{1}$
}

(Received: Jan 10-2016; Accepted : May 3-2016)

\begin{abstract}
In this research, to locate and prioritize suitable areas for flood spreading in Mashhad plain, 10 criteria were used including land use, slope, alluvium thickness, distance to well, distance to subterranean, distance from the village, water table drawdown, permeability coefficient, electrical conductivity, and drainage density. Weighting process was done by Analytic Network Process (ANP) and fuzzy logic. After preparing and weighting the maps of all appropriate measures for locating suitable areas of flood spreading maps based on fuzzy logic and analytic network process model, the final map was prepared for prioritizing suitable areas for flood spreading. Then by applying the limiting layer that is a combination of three criteria of land use, slope and geomorphology, the final map of suitable areas for flood spreading was prepared and prioritized. The results showed that among the 10 factors influencing flood spreading, the thickness of alluvium criteria by weight of 0.27 was identified as the most effective layer in suitable areas for flood spreading. Most of the suitable regions located in slope less than $3 \%$ that represents its considerable impact in implementation of flood spreading. Mashhad plain potential for flood spreading, after removing exception areas (40.8\% of total area), were defined in four inappropriate, relatively appropriate, appropriate and perfectly appropriate classes, that include $2.7,25.9$, 26.5 and $1.5 \%$ of the plain area, respectively.
\end{abstract}

Keywords: Artificial Recharge, Flood Spreading Criteria, Mashhad Plain, Prioritizing.

1. Dept. of Watershed Management, Faculty of Natural Resources and Desert Studies, Yazd Univ., Yazd, Iran.

*: Corresponding Author, Email: farshid_jahanbakhshi@yahoo.com 